\title{
iTRAQ-Based Quantitative Proteomics Analysis of Sprague-Dawley Rats Liver Reveals Perfluorooctanoic Acid-Induced Urea Metabolism Dysfunction
}

Hui Liu

Bengbu Medical College

Fangfang Liu

Bengbu Medical College

Yongbing Zhou

Bengbu Medical College

Nathan Griffin

UoN: University of Newcastle

Sam Faulkner

UoN: University of Newcastle

Huixian Cui

Bengbu Medical College

Li Wang ( $\nabla$ wangli@bbmc.edu.cn )

Bengbu Medical College https://orcid.org/0000-0001-5190-0007

\section{Research Article}

Keywords: perfluorooctanoic acid (PFOA), liver damage, proteomics, urea metabolism, CarbamoylPhosphate Synthase 1 (CPS1)

Posted Date: April 27th, 2021

DOl: https://doi.org/10.21203/rs.3.rs-364795/v1

License: (9) This work is licensed under a Creative Commons Attribution 4.0 International License. Read Full License 


\section{Abstract}

Perfluorooctanoic acid (PFOA) is a typical C8 representative compound of perfluoroalkyl and polyfluoroalkyl substances (PFAS) widely used in industrial and domestic products. It is a persistent organic pollutant found in the environment as well as in the tissues of humans and wildlife. Despite emerging scientific and public interest, the precise mechanisms of PFOA toxicity remain unclear. In this study, male rats were exposed to $1.25,5$, and $20 \mathrm{mg} \mathrm{PFOA} / \mathrm{kg}$ body weight/day for 14 days. Urine samples were also collected and monitored by raising rats in metabolic cages. In vivo results demonstrate that PFOA exposure induces significant hepatocellular hypertrophy and reduced urea metabolism. iTRAQ-based quantitative proteomics analysis of Sprague-Dawley (SD) rats livers identified 3,327 non-redundant proteins of which 112 proteins were significantly upregulated and 80 proteins were downregulated. Gene ontology analysis revealed proteins are primarily involved in cellular, metabolic and single - organism processes. Among them, eight proteins (ACOX1, ACOX2, ACOX3, ACSL1, EHHADH, GOT2, MTOR and ACAA1) were related to oxidation of fatty acids and two proteins (ASS1 and CPS1) were found to be associated with urea cycle disorder. The downregulation of urea synthesis proteins ASS1 and CPS1 after exposure to PFOA was then confirmed through qPCR and western blot analysis. Together, these data demonstrate that PFOA exposure directly influences urea metabolism and identify CPS1 as a potential regulatory target.

\section{Introduction}

Perfluoroalkyl and polyfluoroalkyl substances (PFASs) are a class of synthetic chemicals that are increasingly recognized as a new type of persistent organic pollutants (POPs). POPs contain high-energy C-F covalent bonds in which all hydrogen atoms may be replaced by fluorine atoms. The archetypal PFAS, perfluorooctanoic acid (PFOA), is a perfluorocarboxylic acid with $8 \mathrm{C}$ atoms. The fluorinecontaining special structure of PFOA is responsible for its hydrophobicity, oleophobicity and extremely low surface tension. As such, PFOA is widely used in various commercial and industrial settings including manufacture of textiles, packaging materials, surfactants, pharmaceuticals and fire-extinguishing foam (Convertino et al. 2018; Preston et al. 2018). The widespread use of PFOA has led to the mass production and emission of such compounds. For example, from 1951 to 2015 the global emissions from the production and use of perfluorocarboxylic acid reached 2,610 - 24,100 tons and it is estimated that from 2016 to 2030, the world will continue emission of $20-6,420$ tons of C4-C14 perfluorocarboxylic acid (D'Agostino and Mabury 2017; Gingerich and Mauter 2017; Meng et al. 2017). In addition, the C-F highenergy covalent bond contained in PFOA is an extremely stable chemical bond that allows PFOA to persist in the environment (Cui et al. 2018; Hu et al. 2018). At present, PFOA has been detected in almost all environmental media (Wei et al. 2018; Yao et al. 2018), even in polar regions (Yeung and Dassuncao 2017). Due to its limited biodegradability, accumulation of PFOA has also been detected in birds and mammals (Rigét et al. 2013; Rotander et al. 2012) as well as in multiple reports of accumulation in human serum samples (Gao et al. 2018; Gebbink et al. 2015; Wang et al. 2018). 
In recent years, an increasing number of studies have revealed the toxic effects of PFOA accumulation in organisms (Andersen et al. 2008; Kennedy et al. 2004; Lau et al. 2007; Lau et al. 2004). In general, PFOA accumulation interferes with cellular lipid metabolism, leading to carcinogenicity, liver toxicity, developmental toxicity, immunotoxicity, endocrine interference and neurotoxicity. Previous reports from our lab have demonstrated that PFDoA exposure can restrict amino acid metabolism in rats and thereby influence the synthesis of urea (Liu et al. 2016). In the following study, iTRAQ-based quantitative proteomics was utilized to screen for global proteomic profile alterations in rat livers after exposure to PFOA. We hereby demonstrate the differential expression of ASL 1, ASS1 and CPS1 and identify their role as PFOA sensitive genes related to the urea cycle. These findings clarify the potential mechanisms responsible for PFOA toxicity in vivo and provide reference targets for future intervention and treatment of PFOA accumulation in humans.

\section{Materials And Methods}

\section{Chemicals}

PFOA (CAS No. 335-67-1, 95\% purity) was purchased from Sigma-Aldrich (Merck KGaA, Darmstadt, Germany). Stock solutions of PFOA (0.01 M) were prepared in distilled Milli-Q water. Working solutions were prepared by serial dilution with distilled Milli-Q water. iTRAQ reagents are purchased from $A B I$ (iTRAQ Reagent-8 Plex Multiplex Kit, AB Sciex, USA). $\mathrm{Na}_{2} \mathrm{CO}_{3}$, sodium orthovanadate, sodium pentobarbital, PBS and paraformaldehyde are purchased from Sigma-Aldrich (Merck KGaA, Darmstadt, Germany), Other reagents are AR grade.

\section{Animal treatments}

40 male SPF grade, Sprague-Dawley rats $(200 \pm 10 \mathrm{~g})$ were obtained from Qinglongshan animal breeding company (Nanjing, China) at 6-8 weeks of age. The rats were maintained in a SPF grade facility on a 12$\mathrm{h}$ light/12-h dark cycle and were allowed ad libitum access to a standard diet and pure water. The ambient temperature in the animal room was $23 \pm 1^{\circ} \mathrm{C}$ and the relative humidity was $60 \pm 5 \%$. After one week of adaptation, the rats were randomly separated into four groups of 10 . The treatment rats were given doses of $1.25,5$, and $20 \mathrm{mg}$ PFOA/kg body weight/day by oral gavage for 14 consecutive days. The control animals were also treated with Milli-Q water, accordingly. At the end of the experiment, 7 rats from each group were weighed and anesthetized with sodium pentobarbital (45 mg/kg). Afterwards, blood was drawn from the inferior caval vein, and liver tissues were rapidly collected, weighed, rinsed with PBS, divided into small aliquots, flash frozen in liquid nitrogen before being stored at $-80^{\circ} \mathrm{C}$ until further analysis. The remaining three rats from each group were used for Clinicopathologic analysis. All procedures were performed in accordance with the Ethics Committee of Bengbu Medical College, Anhui Province.

\section{Urine collection and analyses}

10 rats were randomly divided into 2 groups: high dosage group and normal control. Rats were raised in metabolic cages to collect urine samples of $24 \mathrm{~h}$ volume for 14 consecutive days. Urea concentration 
was determined by using commercially available kits (Nanjing Jianchen Bioengineering Institue, China).

\section{Histopathological Examination}

Three livers from each group were fixed in freshly prepared paraformaldehyde (3.7\% in DPBS) and processed sequentially in ethanol, xylene and paraffin. Tissues were then embedded in paraffin, sectioned $(5 \mu \mathrm{m})$, and stained with hematoxylin and eosin (HE stains).

\section{Serum Biochemistry Analysis}

Serum levels of 5'-nucleotidase (5-NT), adenosine deaminase (ADA), albumin (ALB), alkaline phosphatase (ALP), alanine aminotransferase (ALT), aspartate aminotransferase (AST), bilirubin direct (BILD), total bilirubin (BILT), total cholesterol (TCHO), creatinine (CREP), gamma glutamyl transferase (GGT), high density lipoprotein cholesterol (HDL_C), lactic dehydrogenase (LDH), low density lipoprotein cholesterol (LDL_C), total bile acid (TBA), total protein (TP), triglyceride (TG), Urea (UREA), Uric acid (UA) and creatinine (CR) were measured using cobas $® 8000$ modular analyser series (F. Hoffmann-La Roche Ltd).

\section{Protein Preparation, iTRAQ Labeling}

3 individual liquid nitrogen frozen livers from normal control rats and three PFOA treated livers from 20 $\mathrm{mg} \mathrm{PFOA} / \mathrm{kg} / \mathrm{d}$ group were randomly selected for iTRAQ based mass spectrometry analysis. Proteins were extracted by dissolving each liver sample in $300 \mu \mathrm{L}$ of ice-cold $0.1 \mathrm{M} \mathrm{Na}_{2} \mathrm{CO}_{3}$ and $10 \mathrm{mM}$ sodium orthovanadate ( $\mathrm{pH}$ 11) supplemented with protease inhibitor (Roche Complete EDTA Free) and phosphatase inhibitor (Roche), sonicated for $3 \times 10$ seconds and stored on ice. The bicinchoninic acid assay (BCA assay) was used to measure $200 \mu \mathrm{g}$ proteins and mixed with urea/thiourea denaturation buffer to a final concentration at $6 \mathrm{M}$ urea, $2 \mathrm{M}$ thiourea. All protein samples were trypsinized (mass spec grade, Promega). The tryptic peptides in the three biological samples from the control and PFOA-treated groups were labeled with iTRAQ reagents (isobaric tags 115, 116, and 117 for the control; 118, 119 and 121 for the treated group) (iTRAQ Reagent-8 Plex Multiplex Kit, AB Sciex). The iTRAQ labeling was performed according to the manufacturer's protocol.

\section{LC-MS/MS analysis}

Mass spectroscopic (MS) analysis was performed using an Orbitrap Fusion ${ }^{\text {TM }}$ Lumos $^{\text {TM }}$ Tribrid $^{\text {TM }}$ mass spectrometer (Thermo Scientific, USA) and coupled with an EASY-nLC HPLC system (Thermo Scientific, USA). The ITRAQ labeled peptieds were loaded onto a C18-reversed phase column ( $3 \mu \mathrm{m}-\mathrm{C} 18$ resin, 75 $\mu \mathrm{m} \times 15 \mathrm{~cm})$ and separated on an analytical column ( $5 \mu \mathrm{m}-\mathrm{C} 18$ resin, $150 \mu \mathrm{m} \times 2 \mathrm{~cm} ; \mathrm{GmbH}$, Ammerbuch, Germany) using mobile phase Buffer A: $0.5 \%$ formic acid / $\mathrm{H}_{2} \mathrm{O}$ and Buffer B: $0.5 \% \mathrm{FA} / \mathrm{ACN}$ at a flow rate of $300 \mathrm{~nL} / \mathrm{min}$, using a 150 min gradient. Spectra were acquired in Data Dependent Acquisition (DDA) mode.

\section{Database search for peptide and protein identification}

The raw mass data were analyzed using Thermo Proteome Discoverer version 1.4 (ver. 1.4.0.288; Thermo Fisher Scientific) and with a false discovery rate (FDR) $<1 \%$ and expected cutoff or ion score $<5 \%$ (with 
95\% confidence) for searching the Uniprot Rat Complete Proteome database. The following options were used to identify the proteins: Peptide mass tolerance $= \pm 10 \mathrm{ppm}, \mathrm{MS} / \mathrm{MS}$ tolerance $=0.6 \mathrm{Da}$, enzyme $=$ trypsin, missed cleavage $=2$, fixed modification: iTRAQ 8plex $(\mathrm{K})$ and iTRAQ 8plex (N-term), variable modification: oxidation (M), database pattern = decoy.

\section{GO annotation and KEGG pathway analysis}

To analyze the differentially expressed proteins in PFOA treated group compared with normal control group, Gene Ontology (GO) annotation of the identified proteins was performed by searching the GO Web site (http://www.geneontology.org) to catalog the molecular functions, cellular components, and biological processes. Protein interactions and biological pathways were determined using the ResNet database (version 6.5, Ingenuity Systems, Inc.) (KEGG) to better understand these differentially expressed proteins in relation to the published literature.

\section{RNA Isolation and Quantitative real-time PCR}

Rat livers were used for RNA extraction and subsequent qPCR assays. Total RNA of the liver samples was isolated using a Trizol reagent (Ambion, Thermo Fisher Scientific, USA) and the isolation process was performed according to the manufacturer's instructions. Quantitative real-time PCRs (qPCR) were performed on a QuantStudio 3 Real-Time PCR System (Thermo Scientific, USA) using a SYBR Green Real Master Mix Rox (Tiangen, China). The housekeeping gene GAPDH was used as an internal control. The information of the primer pairs are listed in the supplementary table S1. The relative quantification of target genes was calculated based on the $2^{-\triangle \Delta C T}$ method.

\section{Western blotting authentication}

Protein extracts from the control and PFOA exposure group liver tissues were used for western blot analysis. The western blot is briefly as follows: Total proteins from liver of each rats were extracted with RIPA (Thermo Scientific, USA) containing 1 mM PMSF (Sigma-Aldrich, USA) and 1\% phosphatase inhibitor (Sigma-Aldrich, USA). The protein concentration was determined by using a BCA kit (cwbiotech, China). Approximately $40 \mu \mathrm{g}$ of total protein was loaded on $10 \%$ sodium dodecyl sulfate (SDS)polyacrylamide-gels and then transferred to polyvinylidene fluoride membrane (PVDF) tansblot membranes (Amersham Biosciences, Piscataway, NJ, USA). The blotted membranes were blocked in blocking buffer (TBST) for $1 \mathrm{~h}$, and then incubated with primary antibodies dissolved by blocking buffer on a shaker overnight at $4^{\circ} \mathrm{C}$. (The information of the primary antibodies is listed in supplementary table S2.) After washing with TBST for 3 times, the membranes were then incubated with fluorescentconjugated anti-rabbit IgG as the secondary antibody for $1 \mathrm{~h}$ at room temperature, respectively. The immunoreactive bands were photoed and analyzed by Gel Doc XR + Gel Documentation System (BIORAD, USA).

\section{Statistical analyses}

Data were analyzed using SPSS for Windows 17.0 Software (SPSS, Inc., Chicago, IL) and presented as means with standard errors (mean $\pm \mathrm{SE}$ ). Differences between the control and treatment groups were 
determined using one-way analysis of variance (ANOVA). A P value of $<0.05$ was considered statistically significant. OriginPro 2018 software was used to develop graphs (Origin Lab Corporation, USA).

\section{Results}

\section{PFOA cause liver damage and influence urea synthesis}

After 14 days, we find that PFOA exposure may cause body weight loss and significant liver swelling (Fig. 1A-B). Both absolute and relative liver weight were significantly increased by PFOA exposure. HEstained liver slices from PFOA exposed mice also show significant liver swelling (Fig. 1C). In order to quantify the cell size, we counted the number of cells per unit area. The results show that the number of nuclei per area is significantly reduced following PFOA exposure (Fig. 1D); furthermore, this phenomenon has a clear dose-effect relationship with PFOA concentration.

We also monitored the effects of PFOA on metabolism of rats. 14 days of PFOA exposure had no significant influence on daily food intake (Fig. 2A). However, PFOA exposure had significant effect on urea metabolism. Rats exposed with PFOA had significantly lower urea concentration in urine compared with normal control rats (Fig. 2B).

\section{PFOA has effects on sera biochemical parameters}

To investigate the effect of PFOA on urea metabolism, we assayed 19 biochemical indexes in rat serum using a cobas ${ }^{\circledR} 8000$ modular analyser series automatic biochemical analyzer. The results show that 8 indexes have significant changes compared with normal control group (Table 1). These indexes are ALT, ALT/AST, ALP, Urea, TG, TC, HDL-C, LDL-C. In clinical biochemistry, ALT, ALT/AST, ALP are closely related to liver function, serum urea is one of the main indicators of renal function, and TG, TC, HDL-C, LDL-C are closely related to liver lipid metabolism. The levels of ALT, ALT/AST, which are important biochemical indicators of liver damage, were significantly increased in the $20 \mathrm{mg} / \mathrm{kg} / \mathrm{d}$ group. The other indexes which showed no significant changes are listed in supplementary table S3.

While the urea content of urine was significantly decreased in PFOA treated rats compared to normal rats, the level of urea in the serum of the $20 \mathrm{mg} / \mathrm{kg} / \mathrm{d}$ treatment group was significantly increased.

\section{Differentially Expressed Protein Identification and Relative Quantification by iTRAQ Analysis}

Three individual samples were included in the iTRAQ experiment from the control and $20 \mathrm{mg}$ PFOA/ $\mathrm{kg} / \mathrm{d}$ group. The MS/MS analysis identified a total of 25, 506 unique spectra matched to special peptides. Proteome Discover version 2.1 identified a total of 8,369 unique peptides from 2,868 proteins.

\section{Bioinformatics Analysis for Differential Expressed Proteins Induced by PFOA}

Heatmapping, Volcano plot analysis and Venn diagram packaging were used to explore the differentially expressed proteins in PFOA treated group compared with normal control (Fig. 3A, 3B, 3C). Among the 3,327 non-redundant proteins, 112 proteins were significantly upregulated and 80 proteins were downregulated. Significantly changed proteins are shown in the Volcano plot, where the cut $\log _{2}$ (Fold 
Change) was set at 1 and the cutoff P value was 0.05 (Fig. 3B). Among the differentially expressed proteins, upregulated proteins are listed in Table 2 and supplementary table S4; while the downregulated proteins are listed in Table 3.

To further characterize these differentially expressed proteins, we performed GO function annotation analysis via The Gene Ontology (G0) knowledgebase (http://geneontology.org/). Results show that the upregulated and downregulated proteins are mainly involved in the following three biological processes; cellular processes, metabolic process and single - organism processes, and that these processes are localized primarily within the cellular component. When classifying differential proteins by molecular function we find that they are primarily associated with binding and catalytic activity (Fig. 4A, B).

KEGG Pathway analysis (http://www.kegg.jp/kegg/pathway.html) was also used to determine the involvement of differentially expressed proteins in metabolic and cell signaling pathways. The upregulated proteins were primarily involved in peroxisome, PPAR signaling pathway, fatty acid degradation and fatty acid metabolism; while the downregulated proteins were involved in chemical carcinogenesis, biosynthesis of amino acids and drug metabolism (Fig. 5).

\section{Pathway analysis of differentially expressed proteins identified in the rat livers}

Utilizing Ingenuity Pathway Analysis software, eight proteins (ACOX1, ACOX2, ACOX3, ACSL1, EHHADH, GOT2, MTOR and ACAA1) were found to be related to oxidation of fatty acid. (Fig. 6A). Two proteins (ASS1 and CPS1) were found to be associated with urea cycle disorder (Fig. 6B).

\section{Effects of PFOA on urea synthesis related genes}

To investigate the toxic effects of PFOA on urea synthesis related genes, we surveyed the transcription levels of three genes ( $A S L, A S S 1$ and $C P S 1$ ) of key enzymes related to urea cycle using qRT PCR. Compared with the control group, the transcriptional levels of $A S L$ remained unchanged (Fig. 7A), however, the mRNA transcriptional levels of $A S S 1$ and $C P S 1$ were significantly downregulated in the PFOA exposed groups in a dose-dependent manner (Fig. 7B,C). These results are consistent with the proteomic results.

\section{ASS1 and CPS1 are significantly reduced by PFOA exposure}

Expression levels of ASS1 and CPS1 were further verified via western blot. Results show expression levels of ASS1 and CPS1 are significantly downregulated in the PFOA exposed groups in a dose-dependent manner (Fig. 8A, B). These results are also consistent with the proteomic results.

\section{Discussion}

In the present study, the physiological effects of PFOA exposure and its role in liver toxicity was investigated in rat models. We hereby demonstrate that PFOA exposure produces significant body weight loss and liver swelling after 14 days exposure. These results are consistent with previous studies of PFOA exposure experiments in rodents (Lau et al. 2007; Starkov and Wallace 2002). Furthermore, we find that PFOA exposure has a significant effect on urea metabolism. Rats exposed to PFOA have reduced urea 
concentration in urine compared with normal control rats. On the other hand, PFOA exposed rats presented with high urea concentration in the sera. A high urea content in serum rather than in urine may suggest that PFOA exposure either decreases the ability of the liver to metabolize urea, or that urea may leak into blood stream due to the hepatocyte damage.

Investigation of sera biochemistry reveals that levels of ALT, ALP and UREA increased significantly after PFOA exposure. The increased level of ALT and ALP implies that PFOA exposure contributes to liver damage and metabolic disfunction in rats. Levels of TG and TC were significantly decreased in the serum of treatment group suggesting a reduction in metabolic processes. Additionally, the levels of HDL-C and LDL-C were also decreased. A search of KEGG (Kyoto Encyclopedia of Genes and Genomes) metabolic pathway and MetaboAnalyst metabolic pathway found that these indicators are involved in bile acid metabolic pathways and steroid and steroid hormone synthesis pathways.

iTRAQ-based quantitative proteomics were utilized to define the proteomic changes in rat livers after 14 days of PFOA exposure. Totally, 2,868 proteins were identified by MS, among which, 112 proteins were significantly upregulated and 80 proteins were downregulated. Two enzymes identified through quantitative proteomics analysis, ASS1 and CPS1, were found to be closely related to urea metabolism. The differential expression of ASS1 and CPS1, was then confirmed in western blotting experiments. Confirming the downregulation of the enzymes involved in urea synthesis as a result of PFOA exposure provides potential targets for future intervention and treatment of PFOA toxicity.

Additionally, quantitative proteomics experiments also identified 8 differentially expressed proteins (ACOX1, ACOX2, ACOX3, ACSL1, EHHADH, GOT2, MTOR and ACAA1) all related to oxidation of fatty acid. ACOX1, ACOX2 and ACOX3 are enzymes related to the fatty acid beta-oxidation pathway, which catalyzes the desaturation of acyl-CoAs to 2-trans-enoyl-CoAs. ACSL1 is an enzyme responsible for the conversion of free long-chain fatty acids into fatty acyl-CoA esters, and thereby plays a key role in lipid biosynthesis and fatty acid degradation. EHHADH is a bifunctional enzyme that is one of the four enzymes of the peroxisomal beta-oxidation pathway. ACCAA1 is a protein involved in the beta-oxidation system of the peroxisomes. The upregulation of these proteins in the livers of PFOA exposed rats implies an increase in liver fatty acid oxidation. This result is consistent with our finding of low levels of TG present in rat liver and sera. Previous studies have also suggested that PFOA exposure may cause accelerated fatty acid oxidation (Chen et al. 2020; Kudo et al. 2006; Yu et al. 2016). In our study, urea-cycle enzymes ASS1 and CPS1 were also downregulated after PFOA exposure, implying that urea synthesis is decreased in liver. Therefore, PFOA exposure accelerated the $\beta$-oxidation of fatty acid in the liver of rats, and at the same time inhibited the synthesis of urea in the liver.

\section{Conclusion}

In summary, after 14 days of PFOA exposure, rat livers displayed significant liver swelling and aberrant levels of TG, TC, HDL-C, LDL-C and urea. iTRAQ-based quantitative proteomics revealed that deregulated proteins ACOX1, ACOX2, ACOX3, ACSL1, EHHADH, GOT2, MTOR and ACAA1 are all related to oxidation of 
fatty acid while ASS1 and CPS1 are associated with urea cycle disorder. Overall, this study provides insight into specific mechanisms of hepatotoxicity as a result of PFOA exposure.

\section{Declarations}

Authors' contributions H.L., and L.W., are co-senior authors. H.L., and L.W. designed the study; H.L., FF.L., YB.Z., HX.C., and L.W. carried out the experimental work and analyzed the results; H.L., N.G., S.F. and L.W. wrote the manuscript. All co-authors have edited the manuscript and approved the final version.

Funding This work was supported by the National Natural Science Foundation of China (grants No. 21806002), Anhui Provincial key projects of excellent talent supporting program for universities (grants No. gxyqZD2020028), Key Projects of Natural Science Research of Colleges and Universities in Anhui Province (grants No. KJ2019A0315) and 512 Talent Cultivation Program of Bengbu Medical College (grants No. by51201303).

Data availability All data generated or analyzed during this study were included in this published article, Supplementary table S1, Supplementary table S2, Supplementary table S3, Supplementary table S4 were availble from Springer link.

\section{Compliance with ethical standards}

Conflicts of interest The authors declare no conflict of interest.

Ethical approval All authors declared that they had no known competing financial interests or personal relationships that seemed to affect the work reported in this article. All authors followed the ethical responsibilities of this journal.

Consent to participate and publish All authors participated and approved the final manuscript to be published.

\section{References}

1. Andersen ME et al (2008) Perfluoroalkyl acids and related chemistries-toxicokinetics and modes of action Toxicological sciences: an. official journal of the Society of Toxicology 102:3-14. doi:10.1093/toxsci/kfm270

2. Chen $Z$ et al (2020) Dysregulated lipid and fatty acid metabolism link perfluoroalkyl substances exposure and impaired glucose metabolism in young adults. Environment international 145:106091. doi:10.1016/j.envint.2020.106091

3. Convertino $\mathrm{M}$ et al (2018) Stochastic Pharmacokinetic-Pharmacodynamic Modeling for Assessing the Systemic Health Risk of Perfluorooctanoate (PFOA) Toxicological sciences: an. official journal of the Society of Toxicology 163:293-306. doi:10.1093/toxsci/kfy035 
4. Cui Q, Pan Y, Zhang H, Sheng N, Wang J, Guo Y, Dai J (2018) Occurrence and Tissue Distribution of Novel Perfluoroether Carboxylic and Sulfonic Acids and Legacy Per/Polyfluoroalkyl Substances in Black-Spotted Frog. (Pelophylax nigromaculatus) 52:982-990. doi:10.1021/acs.est.7b03662

5. D'Agostino LA, Mabury SA (2017) Certain Perfluoroalkyl and Polyfluoroalkyl Substances Associated with Aqueous Film Forming Foam Are Widespread in Canadian. Surface Waters Environmental science technology 51:13603-13613. doi:10.1021/acs.est.7b03994

6. Gao K et al (2018) An integrated method for simultaneously determining 10 classes of per- and polyfluoroalkyl substances in one drop of human serum. Analytica chimica acta 999:76-86. doi:10.1016/j.aca.2017.10.038

7. Gebbink WA, Glynn A, Berger U (2015) Temporal changes (1997-2012) of perfluoroalkyl acids and selected precursors (including isomers) in Swedish human serum Environmental pollution (Barking, Essex: 1987) 199:166-173 doi:10.1016/j.envpol.2015.01.024

8. Gingerich DB, Mauter MS (2017) Air Emissions Damages from Municipal Drinking Water Treatment Under Current and Proposed. Regulatory Standards 51:10299-10306. doi:10.1021/acs.est.7b03461

9. Hu XC et al (2018) Can profiles of poly- and Perfluoroalkyl substances (PFASs) in human serum provide information on major exposure sources? Environmental health: a global access science source 17:11. doi:10.1186/s12940-018-0355-4

10. Kennedy GL Jr et al (2004) The toxicology of perfluorooctanoate. Crit Rev Toxicol 34:351-384. doi:10.1080/10408440490464705

11. Kudo N, Suzuki-Nakajima E, Mitsumoto A, Kawashima Y (2006) Responses of the liver to perfluorinated fatty acids with different carbon chain length in male and female mice:in relation to induction of hepatomegaly, peroxisomal beta-oxidation and microsomal 1-

acylglycerophosphocholine acyltransferase Biol Pharm Bull 29:1952-1957 doi:10.1248/bpb.29.1952

12. Lau C, Anitole K, Hodes C, Lai D, Pfahles-Hutchens A, Seed J (2007) Perfluoroalkyl acids: a review of monitoring and toxicological findings Toxicological sciences: an. official journal of the Society of Toxicology 99:366-394. doi:10.1093/toxsci/kfm128

13. Lau C, Butenhoff JL, Rogers JM (2004) The developmental toxicity of perfluoroalkyl acids and their derivatives. Toxicol Appl Pharmcol 198:231-241. doi:10.1016/j.taap.2003.11.031

14. Liu H, Zhang H, Cui R, Guo X, Wang D, Dai J (2016) Activation of peroxisome proliferator-activated receptor a ameliorates perfluorododecanoic acid-induced production of reactive oxygen species in rat liver. Arch Toxicol 90:1383-1397. doi:10.1007/s00204-015-1559-9

15. Meng J, Lu Y, Wang T, Wang P, Giesy JP, Sweetman AJ, Li Q (2017) Life cycle analysis of perfluorooctanoic acid (PFOA) and its salts in China Environmental. science pollution research international 24:11254-11264. doi:10.1007/s11356-017-8678-1

16. Preston EV et al (2018) Maternal Plasma per- and Polyfluoroalkyl Substance Concentrations in Early Pregnancy and Maternal and Neonatal Thyroid Function in a Prospective Birth Cohort: Project Viva (USA). Environmental health perspectives 126:027013. doi:10.1289/ehp2534 
17. Rigét F, Bossi R, Sonne C, Vorkamp K, Dietz R (2013) Trends of perfluorochemicals in Greenland ringed seals and polar bears: indications of shifts to. decreasing trends Chemosphere 93:16071614. doi:10.1016/j.chemosphere.2013.08.015

18. Rotander A et al (2012) Increasing levels of long-chain perfluorocarboxylic acids (PFCAs) in Arctic and North Atlantic marine mammals, 1984-2009. Chemosphere 86:278-285. doi:10.1016/j.chemosphere.2011.09.054

19. Starkov AA, Wallace KB (2002) Structural determinants of fluorochemical-induced mitochondrial dysfunction Toxicological sciences: an. official journal of the Society of Toxicology 66:244-252. doi:10.1093/toxsci/66.2.244

20. Wang H et al (2018) Perfluoroalkyl substances, glucose homeostasis, and gestational diabetes mellitus in Chinese pregnant women: A repeat measurement-based prospective study. Environment international 114:12-20. doi:10.1016/j.envint.2018.01.027

21. Wei C, Wang Q, Song X, Chen X, Fan R, Ding D, Liu Y (2018) Distribution, source identification and health risk assessment of PFASs and two PFOS alternatives in groundwater from non-industrial areas. Ecotoxicol Environ Saf 152:141-150. doi:10.1016/j.ecoenv.2018.01.039

22. Yao Y, Zhao Y, Sun H (2018) Per- and Polyfluoroalkyl Substances (PFASs) in Indoor Air and Dust from Homes and Various Microenvironments in China. Implications for Human Exposure 52:3156-3166. doi:10.1021/acs.est.7b04971

23. Yeung LWY, Dassuncao C (2017) Vertical Profiles, Sources, and Transport of PFASs. in the Arctic Ocean 51:6735-6744. doi:10.1021/acs.est.7b00788

24. Yu N et al (2016) Effects of Perfluorooctanoic Acid on Metabolic Profiles in Brain and Liver of Mouse Revealed by a High-throughput. Targeted Metabolomics Approach Scientific reports 6:23963. doi:10.1038/srep23963

\section{Tables}

Table 1. Alteration of serum biochemical levels $(n=7)$ after PFOA exposure, data are mean $\pm S E$, significantly different from control group. 


\begin{tabular}{|c|c|c|c|c|c|c|}
\hline & Ctrl & $1.25 \mathrm{mg} / \mathrm{kg} / \mathrm{d}$ & $5 \mathrm{mg} / \mathrm{kg} / \mathrm{d}$ & $20 \mathrm{mg} / \mathrm{kg} / \mathrm{d}$ & $\begin{array}{l}\mathrm{F} \\
\text { value }\end{array}$ & $\begin{array}{l}P \\
\text { value }\end{array}$ \\
\hline ALT & $27.81 \pm 2.51$ & $35.60 \pm 2.41$ & $31.47 \pm 1.96$ & $56.00 \pm 12.00^{* *}$ & 3.96 & 0.02 \\
\hline ALT/AST & $0.28 \pm 0.04$ & $0.29 \pm 0.02$ & $0.26 \pm 0.02$ & $0.46 \pm 0.02^{* *}$ & 13.13 & 0.00 \\
\hline ALP & $159.14 \pm 11.33$ & $192.29 \pm 17.21$ & $203.29 \pm 13.67^{*}$ & $210.71 \pm 12.82^{*}$ & 2.67 & 0.07 \\
\hline Urea & $7.01 \pm 0.49$ & $6.41 \pm 0.45$ & $6.26 \pm 0.32$ & $8.83 \pm 0.44^{* *}$ & 7.5 & 0.00 \\
\hline TG & $0.72 \pm 0.11$ & $0.55 \pm 0.06$ & $0.46 \pm 0.04^{*}$ & $0.55 \pm 0.09$ & 1.88 & 0.16 \\
\hline $\mathrm{TC}$ & $1.42 \pm 0.10$ & $1.07 \pm 0.12$ & $0.97 \pm 0.11^{*}$ & $1.59 \pm 0.22$ & 3.93 & 0.02 \\
\hline HDL - C & $0.96 \pm 0.07$ & $0.83 \pm 0.08$ & $0.73 \pm 0.09$ & $1.06 \pm 0.11$ & 2.69 & 0.07 \\
\hline LDL - C & $0.25 \pm 0.03$ & $0.13 \pm 0.02$ & $0.16 \pm 0.03$ & $0.38 \pm 0.11$ & 3.63 & 0.03 \\
\hline
\end{tabular}

${ }^{\star} \mathrm{p}<0.05, * \star \mathrm{p}<0.01$

Table 2. Lists of upregulated Proteins (higher than 2 fold) Identified by iTRAQ in rat livers after 20 $\mathrm{mg} / \mathrm{kg} /$ day PFOA Exposure for 14 Days 


\begin{tabular}{|c|c|c|c|c|}
\hline Accession & Description & $\begin{array}{l}\text { Unique } \\
\text { Peptides }\end{array}$ & $\begin{array}{l}\text { Fold } \\
\text { changes }\end{array}$ & $\begin{array}{l}p \\
\text { value }\end{array}$ \\
\hline P07896 & Peroxisomal bifunctional enzyme & 51 & 3.76 & 0.000 \\
\hline O88267 & Acyl-coenzyme A thioesterase 1 & 3 & 3.73 & 0.000 \\
\hline P07871 & 3-ketoacyl-CoA thiolase B, peroxisomal & 2 & 3.53 & 0.000 \\
\hline O55171 & Acyl-coenzyme $\mathrm{A}$ thioesterase 2 , mitochondrial & 5 & 3.42 & 0.000 \\
\hline D4A317 & Protein Ccdc18 & 1 & 3.19 & 0.000 \\
\hline P23965 & Enoyl-CoA delta isomerase 1, mitochondrial & 14 & 3.15 & 0.000 \\
\hline $\mathrm{AOAOH} 2 \mathrm{UI} 21$ & Carnitine O-acetyltransferase & 24 & 3.10 & 0.000 \\
\hline P07872 & Peroxisomal acyl-coenzyme A oxidase 1 & 30 & 3.08 & 0.000 \\
\hline A0A140UHW7 & Cytochrome P450 2B1 & 5 & 3.07 & 0.000 \\
\hline P13601 & Aldehyde dehydrogenase, cytosolic 1 & 13 & 2.99 & 0.000 \\
\hline P08516 & Cytochrome P450 4A10 & 14 & 2.96 & 0.000 \\
\hline Q99N59 & Alpha-amylase & 2 & 2.82 & 0.000 \\
\hline P16970 & ATP-binding cassette sub-family $\mathrm{D}$ member 3 & 23 & 2.81 & 0.000 \\
\hline Q66H58 & von Willebrand factor A domain-containing protein 9 & 1 & 2.76 & 0.000 \\
\hline P20817 & Cytochrome P450 4A14 & 5 & 2.76 & 0.000 \\
\hline A0A0G2JSR8 & $\begin{array}{l}\text { Cytochrome P450, family } 17 \text {, subfamily a, polypeptide } \\
1\end{array}$ & 3 & 2.64 & 0.009 \\
\hline P51647 & Retinal dehydrogenase 1 & 13 & 2.63 & 0.000 \\
\hline P20816 & Cytochrome P450 4A2 & 6 & 2.61 & 0.003 \\
\hline D3ZSE3 & Protein Acot6 & 1 & 2.60 & 0.034 \\
\hline A0A0G2K1S6 & Malic enzyme & 18 & 2.56 & 0.000 \\
\hline Q95567 & $\begin{array}{l}\text { Mature alpha chain of major histocompatibility complex } \\
\text { class I antigen (Fragment) }\end{array}$ & 1 & 2.49 & 0.001 \\
\hline A0A0G2K455 & Carboxylic ester hydrolase & 3 & 2.47 & 0.001 \\
\hline O70597 & Peroxisomal membrane protein $11 \mathrm{~A}$ & 7 & 2.39 & 0.000 \\
\hline Q62651 & $\begin{array}{l}\text { Delta(3,5)-Delta(2,4)-dienoyl-CoA isomerase, } \\
\text { mitochondrial }\end{array}$ & 13 & 2.38 & 0.000 \\
\hline G3V734 & $\begin{array}{l}\text { 2,4-dienoyl CoA reductase 1, mitochondrial, isoform } \\
\text { CRA_a }\end{array}$ & 13 & 2.36 & 0.000 \\
\hline P80299 & Bifunctional epoxide hydrolase 2 & 18 & 2.33 & 0.037 \\
\hline A0A140UHX9 & Protein Ccz1b & 2 & 2.27 & 0.005 \\
\hline A0A0G2JYI5 & Monoglyceride lipase & 10 & 2.25 & 0.000 \\
\hline P79599 & $\begin{array}{l}\text { Mature alpha chain of major histocompatibility complex } \\
\text { class I antigen (Fragment) }\end{array}$ & 1 & 2.20 & 0.002 \\
\hline F1LWL5 & Protein Gemin4 & 1 & 2.20 & 0.006 \\
\hline Q5DT04 & UDP-glucuronosyltransferase & 7 & 2.19 & 0.002 \\
\hline F8WG67 & Acyl-CoA thioesterase 7, isoform CRA_a & 7 & 2.18 & 0.001 \\
\hline A0A0G2JT98 & Cytochrome P450 3A2 & 2 & 2.16 & 0.004 \\
\hline P17764 & Acetyl-CoA acetyltransferase, mitochondrial & 23 & 2.15 & 0.002 \\
\hline Q6T5F0 & UDP-glucuronosyltransferase & 1 & 2.14 & 0.000 \\
\hline P22791 & Hydroxymethylglutaryl-CoA synthase, mitochondrial & 29 & 2.13 & 0.000 \\
\hline P05183 & Cytochrome P450 3A2 & 8 & 2.11 & 0.002 \\
\hline Q4V8F9 & Hydroxysteroid dehydrogenase-like protein 2 & 12 & 2.10 & 0.000 \\
\hline D3ZIQ1 & Protein Acot4 & 7 & 2.10 & 0.000 \\
\hline 070253 & Muscle carnitine palmitoyltransferase I & 5 & 2.08 & 0.015 \\
\hline $\mathrm{B} 2 \mathrm{RZCO}$ & Aig1 protein & 1 & 2.07 & 0.001 \\
\hline P24464 & Cytochrome P450 4A12 & 1 & 2.07 & 0.000 \\
\hline P97524 & Very long-chain acyl-CoA synthetase & 3 & 2.05 & 0.000 \\
\hline B2RYW4 & Mitochondrial ribosomal protein L53 & 2 & 2.05 & 0.005 \\
\hline Q8VHKO & Acyl-coenzyme A thioesterase 8 & 9 & 2.02 & 0.000 \\
\hline
\end{tabular}

Table 3. Lists of downregulated Proteins Identified by iTRAQ in rat livers after $20 \mathrm{mg} / \mathrm{kg} / \mathrm{day}$ PFOA Exposure for 14 Days 
Page 14/24 


\begin{tabular}{|c|c|c|c|c|c|c|}
\hline Accession & Description & $\begin{array}{l}\text { Unique } \\
\text { Peptides }\end{array}$ & $\begin{array}{l}\begin{array}{l}\text { Fold } \\
\text { changes }\end{array} \\
\end{array}$ & $\begin{array}{l}p \\
\text { value }\end{array}$ & & \\
\hline Q617R1 & $\begin{array}{l}\text { Dehydrogenase/reductase (SDR family) } \\
\text { member } 7\end{array}$ & 2 & 0.11 & 0.001 & & \\
\hline F7ET54 & Protein LOC298116 & 2 & 0.24 & 0.002 & & \\
\hline M3ZCQ0 & Sulfotransferase & 12 & 0.27 & 0.001 & & \\
\hline F1LRV6 & GMP reductase & 1 & 0.32 & 0.008 & & \\
\hline Q4V819 & Protein Ugp2 & 20 & 0.37 & 0.004 & & \\
\hline Q07523 & Hydroxyacid oxidase 2 & 16 & 0.39 & 0.003 & & \\
\hline B6ID08 & Metallothionein & 3 & 0.41 & 0.031 & & \\
\hline F1M0G0 & Protein Rgs17 & 1 & 0.43 & 0.001 & & \\
\hline Q03336 & Regucalcin & 20 & 0.43 & 0 & & \\
\hline P14141 & Carbonic anhydrase 3 & 13 & 0.44 & 0.001 & & \\
\hline A0A0G2K950 & Protein Papss2 & 23 & 0.46 & 0.001 & & \\
\hline P10867 & L-gulonolactone oxidase & 1 & 0.48 & 0.024 & & \\
\hline P04182 & Ornithine aminotransferase, mitochondrial & 16 & 0.48 & 0.029 & & \\
\hline A0A0G2JWH3 & Condensin complex subunit 1 & 1 & 0.49 & 0.026 & & \\
\hline P04799 & Cytochrome P450 1A2 & 20 & 0.49 & 0.001 & & \\
\hline Q4QQW7 & $\begin{array}{l}\text { Cytochrome P450, family } 2 \text {, subfamily c, } \\
\text { polypeptide } 7\end{array}$ & 10 & 0.49 & 0.029 & & \\
\hline $\mathrm{P} 16232$ & $\begin{array}{l}\text { Corticosteroid 11-beta-dehydrogenase } \\
\text { isozyme } 1\end{array}$ & 12 & 0.5 & 0 & & \\
\hline Q5BK21 & Protein Tm7sf2 & 3 & 0.51 & 0 & & \\
\hline P07379 & $\begin{array}{l}\text { Phosphoenolpyruvate carboxykinase, } \\
\text { cytosolic [GTP] }\end{array}$ & 23 & 0.51 & 0.013 & & \\
\hline P09034 & Argininosuccinate synthase & 26 & 0.55 & 0 & & \\
\hline P04905 & Glutathione S-transferase Mu 1 & 12 & 0.55 & 0.003 & & \\
\hline Q569D0 & Sulfotransferase & 2 & 0.55 & 0.006 & & \\
\hline A0A0G2JSI0 & $\begin{array}{l}\text { Dimethylaniline monooxygenase } \\
\text { [N-oxide-forming] }\end{array}$ & 20 & 0.57 & 0.011 & & \\
\hline $\mathrm{A} 0 \mathrm{AOH} 2 \mathrm{UHH} 2$ & Serum amyloid P-component & 6 & 0.57 & 0 & & \\
\hline P09606 & Glutamine synthetase & 21 & 0.57 & 0 & & \\
\hline P36365 & $\begin{array}{l}\text { Dimethylaniline monooxygenase } \\
\text { [N-oxide-forming] } 1\end{array}$ & 19 & 0.57 & 0.004 & & \\
\hline $\mathrm{P} 28037$ & $\begin{array}{l}\text { Cytosolic } 10 \text {-formyltetrahydrofolate } \\
\text { dehydrogenase }\end{array}$ & 49 & 0.57 & 0.001 & & \\
\hline B1WBN9 & Pyruvate kinase & 24 & 0.58 & 0 & & \\
\hline Q6AZ33 & Biliverdin reductase $\mathrm{A}$ & 1 & 0.58 & 0.006 & & \\
\hline D3ZTP0 & 10 -formyltetrahydrofolate dehydrogenase & 32 & 0.58 & 0.006 & & \\
\hline P17988 & Sulfotransferase $1 \mathrm{~A} 1$ & 16 & 0.58 & 0.003 & & \\
\hline P24008 & 3-oxo-5-alpha-steroid 4-dehydrogenase 1 & 3 & 0.58 & 0.001 & & \\
\hline $\mathrm{A} 0 \mathrm{~A} 0 \mathrm{G} 2 \mathrm{~K} 2 \mathrm{P} 4$ & Protein Cyp2t1 & 3 & 0.59 & 0.007 & & \\
\hline P70552 & $\begin{array}{l}\text { GTP cyclohydrolase } 1 \text { feedback regulatory } \\
\text { protein }\end{array}$ & 2 & 0.59 & 0.011 & & \\
\hline D4AE49 & Protein Skiv2l2 & 1 & 0.59 & 0.012 & & \\
\hline P49890 & Estrogen sulfotransferase Ste2 & 5 & 0.6 & 0.004 & & \\
\hline P49889 & Estrogen sulfotransferase, isoform 3 & 3 & 0.6 & 0.035 & & \\
\hline F1LQS6 & RCG61833 & 27 & 0.61 & 0 & & \\
\hline Q6AZ23 & Caspase 6 & 2 & 0.61 & 0.018 & & \\
\hline P02761 & $\begin{array}{l}\text { Major urinary protein } \mathrm{OS}=\text { Rattus norvegicus } \\
\mathrm{PE}=1 \mathrm{SV}=1\end{array}$ & 3 & 0.61 & 0.021 & & \\
\hline D4A253 & Protein LOC100361547 & 1 & 0.61 & 0.022 & & \\
\hline B6DYQ2 & Glutathione S-transferase & 13 & 0.61 & 0.001 & & \\
\hline D4A7S6 & LOC363020 (Predicted) & 1 & 0.61 & 0.022 & & \\
\hline P21213 & \multicolumn{2}{|l|}{ Histidine ammonia-lyase } & \multicolumn{2}{|c|}{24} & 0.61 & 0.002 \\
\hline D4A2Y9 & \multicolumn{2}{|c|}{ Peroxisomal biogenesis factor 13 (Predicted) } & \multicolumn{2}{|c|}{2} & 0.61 & 0.002 \\
\hline Q64654 & \multicolumn{2}{|l|}{ Lanosterol 14-alpha demethylase } & \multicolumn{2}{|c|}{13} & 0.62 & 0 \\
\hline P28492 & \multicolumn{2}{|c|}{ Glutaminase liver isoform, mitochondrial } & \multicolumn{2}{|c|}{8} & 0.62 & 0.001 \\
\hline P62329 & \multicolumn{2}{|l|}{ Thymosin beta-4 } & \multicolumn{2}{|c|}{4} & 0.62 & 0.001 \\
\hline O35394 & \multicolumn{2}{|l|}{ Prenylated Rab acceptor protein 1} & \multicolumn{2}{|c|}{2} & 0.62 & 0.036 \\
\hline A0A0G2JSM2 & \multicolumn{2}{|l|}{60 kDa lysophospholipase } & \multicolumn{2}{|c|}{4} & 0.63 & 0 \\
\hline D3ZM33 & \multicolumn{2}{|l|}{ Protein LOC100362298 } & \multicolumn{2}{|c|}{9} & 0.63 & 0.002 \\
\hline F1LN88 & \multicolumn{2}{|c|}{ Aldehyde dehydrogenase, mitochondrial } & \multicolumn{2}{|c|}{1} & 0.63 & 0 \\
\hline D3ZBM3 & Ferrochelatase & & \multicolumn{2}{|c|}{7} & 0.63 & 0.011 \\
\hline
\end{tabular}




\begin{tabular}{|c|c|c|c|c|}
\hline Q6IRS6 & Fetub protein & 9 & 0.63 & 0.001 \\
\hline $\mathrm{A} 0 \mathrm{AOH} 2 \mathrm{UHB} 1$ & 3-keto-steroid reductase & 3 & 0.64 & 0.007 \\
\hline A0A140TAC7 & L-gulonolactone oxidase & 1 & 0.64 & 0.003 \\
\hline Q923M1 & $\begin{array}{l}\text { Mitochondrial peptide methionine sulfoxide } \\
\text { reductase }\end{array}$ & 8 & 0.64 & 0.003 \\
\hline AOAOAOMYOO & $\begin{array}{l}\text { Short/branched chain-specific acyl-CoA } \\
\text { dehydrogenase, mitochondrial }\end{array}$ & 12 & 0.64 & 0.014 \\
\hline F1MAR6 & Protein Prodh1 & 10 & 0.64 & 0.006 \\
\hline P12336 & $\begin{array}{l}\text { Solute carrier family } 2 \text {, facilitated glucose } \\
\text { transporter member } 2\end{array}$ & 5 & 0.64 & 0 \\
\hline P24470 & Cytochrome P450 2C23 & 19 & 0.64 & 0.001 \\
\hline D3ZCM7 & Protein Tle1 & 1 & 0.64 & 0.004 \\
\hline P52759 & Ribonuclease UK114 & 9 & 0.64 & 0.001 \\
\hline P07756 & $\begin{array}{l}\text { Carbamoyl-phosphate synthase } \\
\text { [ammonia], mitochondrial }\end{array}$ & 97 & 0.64 & 0 \\
\hline P36201 & Cysteine-rich protein 2 & 5 & 0.64 & 0 \\
\hline P24090 & Alpha-2-HS-glycoprotein & 11 & 0.65 & 0.007 \\
\hline O88867 & Kynurenine 3-monooxygenase & 11 & 0.65 & 0.003 \\
\hline A0A0G2JZ73 & Alpha-1-antiproteinase & 15 & 0.65 & 0.014 \\
\hline P50554 & $\begin{array}{l}\text { 4-aminobutyrate aminotransferase, } \\
\text { mitochondrial }\end{array}$ & 16 & 0.65 & 0.001 \\
\hline F1M6G0 & Protein RGD1565693 & 1 & 0.65 & 0.012 \\
\hline Q6P691 & Protein $\mathrm{C} 2 \mathrm{~cd} 2$ & 1 & 0.65 & 0.001 \\
\hline Q9QXT3 & $\mathrm{N}$-acetyltransferase 8 & 2 & 0.65 & 0.008 \\
\hline Q6AYW2 & Phenylalanine hydroxylase & 20 & 0.66 & 0.004 \\
\hline D3Z9U2 & CD163 antigen (Predicted) & 4 & 0.66 & 0 \\
\hline Q6AYC4 & Macrophage-capping protein & 3 & 0.66 & 0.005 \\
\hline G3V8G5 & Golgi apparatus protein 1 & 2 & 0.66 & 0.025 \\
\hline Q4KM35 & Proteasome subunit beta type- 10 & 4 & 0.66 & 0.001 \\
\hline B2RYT7 & $\begin{array}{l}\text { Haloacid dehalogenase-like hydrolase } \\
\text { domain containing } 3\end{array}$ & 9 & 0.66 & 0 \\
\hline P09811 & Glycogen phosphorylase, liver form & 49 & 0.66 & 0.007 \\
\hline A0A0G2K7T2 & $\begin{array}{l}\text { Bifunctional UDP-N-acetylglucosamine } \\
\text { 2-epimerase/N-acetylmannosamine kinase }\end{array}$ & 19 & 0.66 & 0.026 \\
\hline
\end{tabular}

\section{Figures}




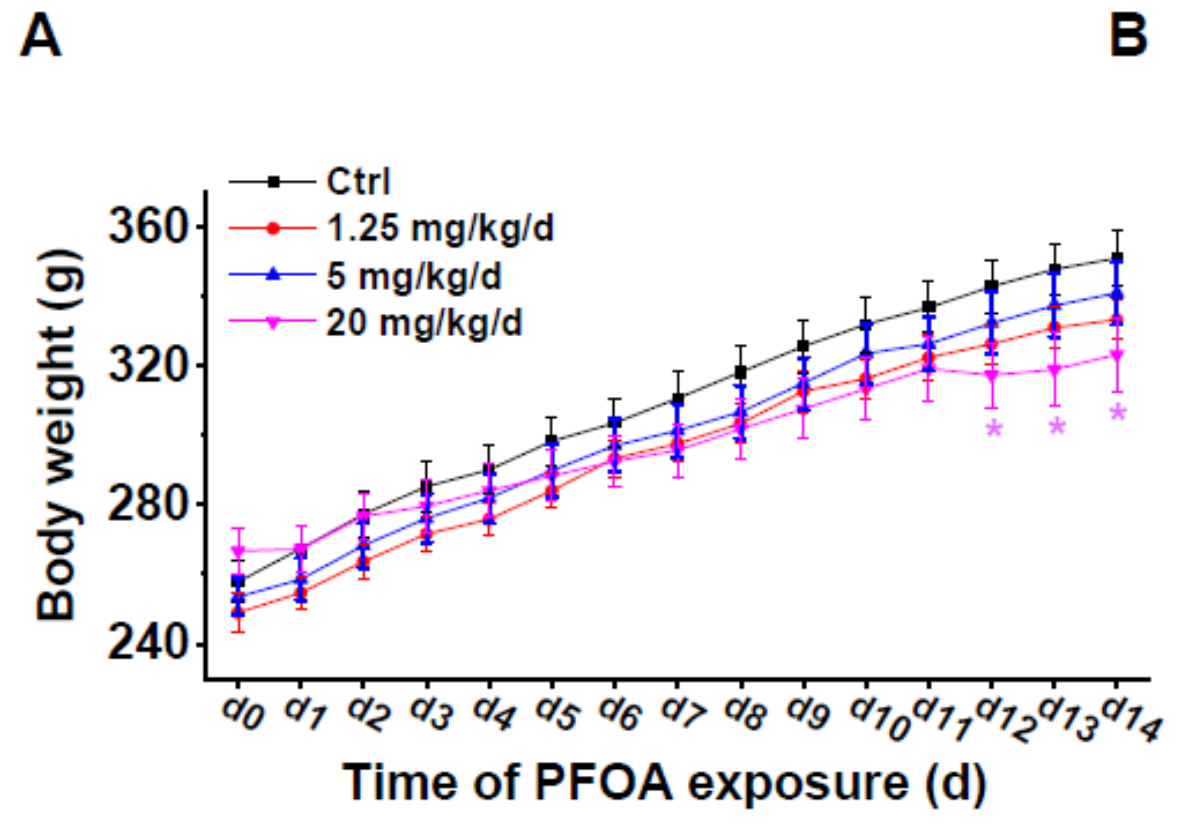

C

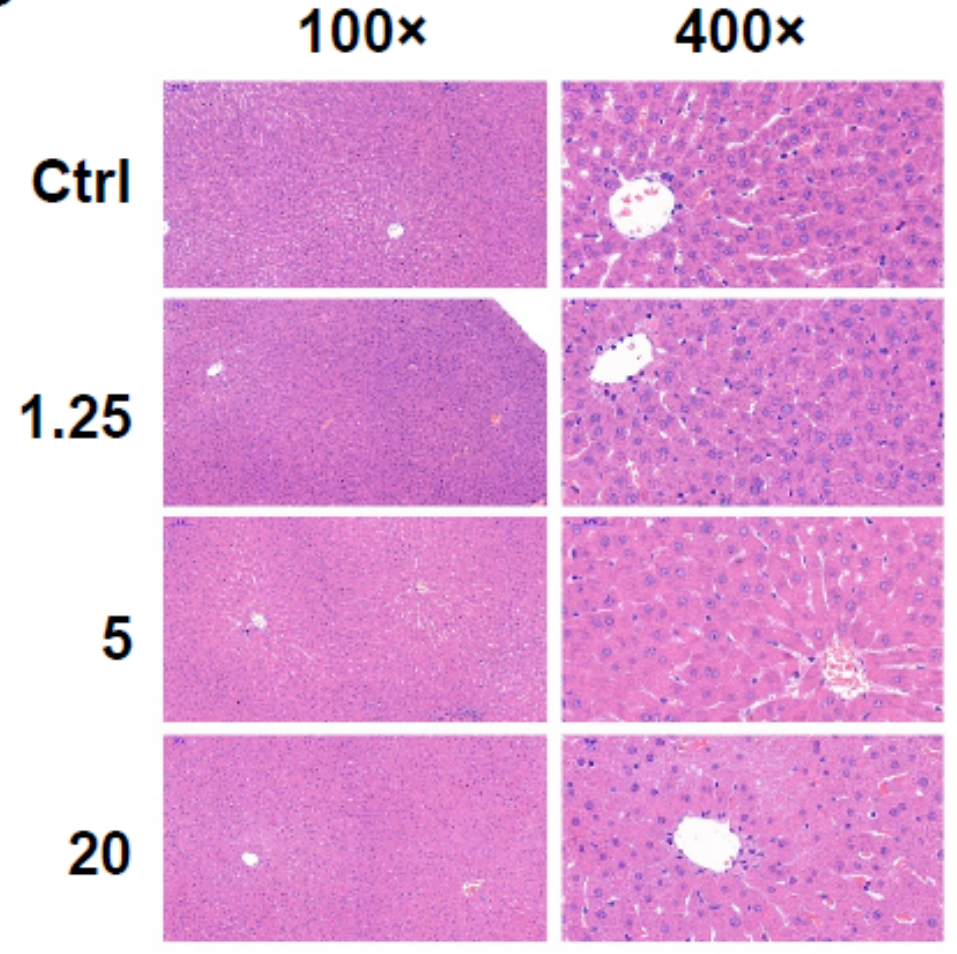

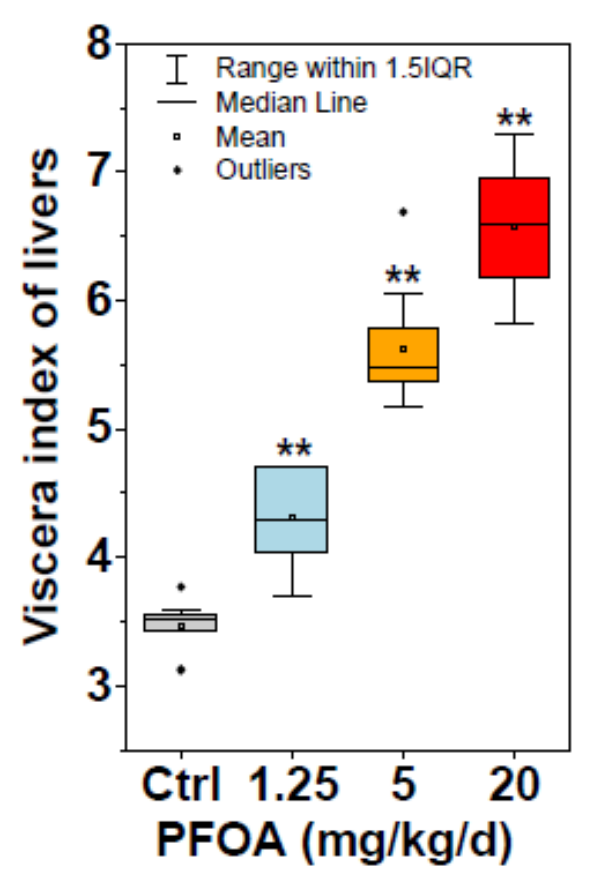

D

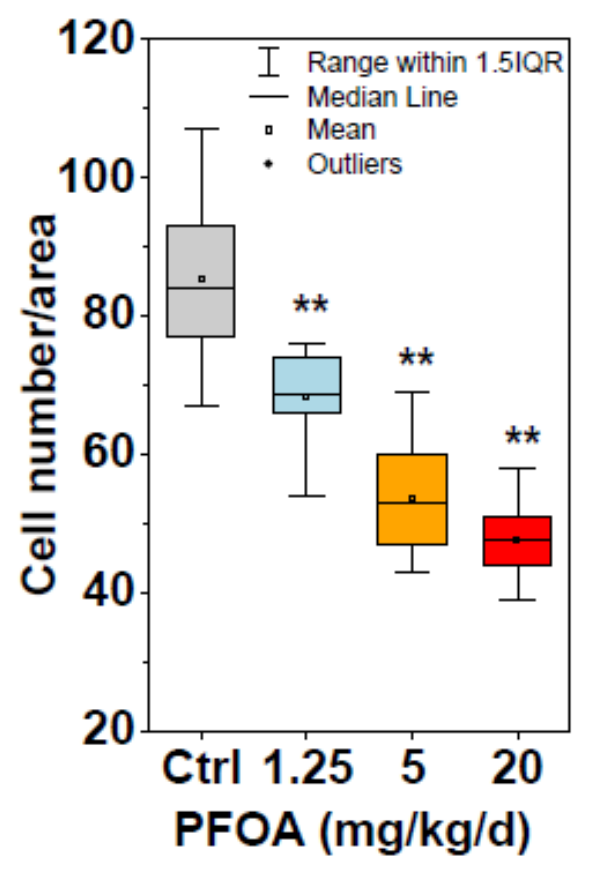

\section{Figure 1}

PFOA exposure can cause body weight to lose and significant liver Swelling. A. Body weight gain during PFOA exposure for 14 days in each group. B. Organ index of liver (relative liver weight) was significantly increased by PFOA exposure. C. HE-stained liver slices from PFOA exposed mice compared with normal control (100x and 400x original mag). D. Nuclei number per unit area. Data points represent individual 
replicates (C: control; L: 1.25 mg/kg/d; M: $5 \mathrm{mg} / \mathrm{kg} / \mathrm{d} ; \mathrm{H}: 20 \mathrm{mg} / \mathrm{kg} / \mathrm{d}$ ). Mean $\pm \mathrm{SEM} ; \mathrm{n}=10 ;{ }^{*} \mathrm{p}<0.05 ;{ }^{* * p}$ $<0.01$ (control group vs. PFOA treated groups).

A

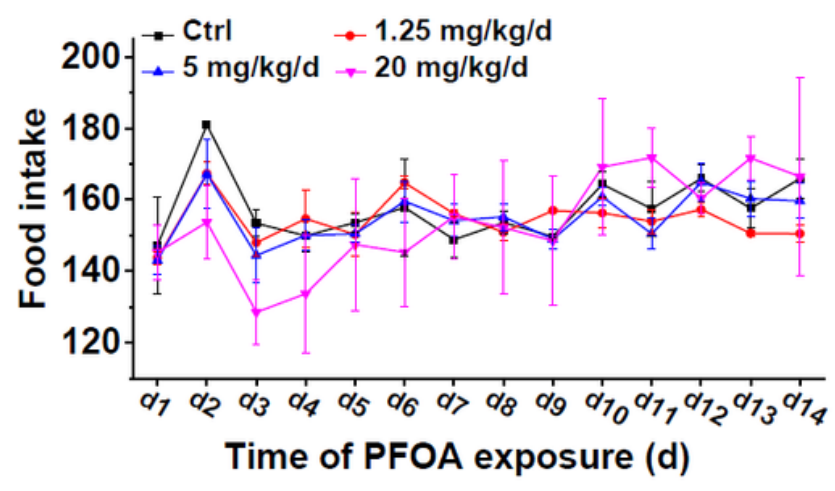

B

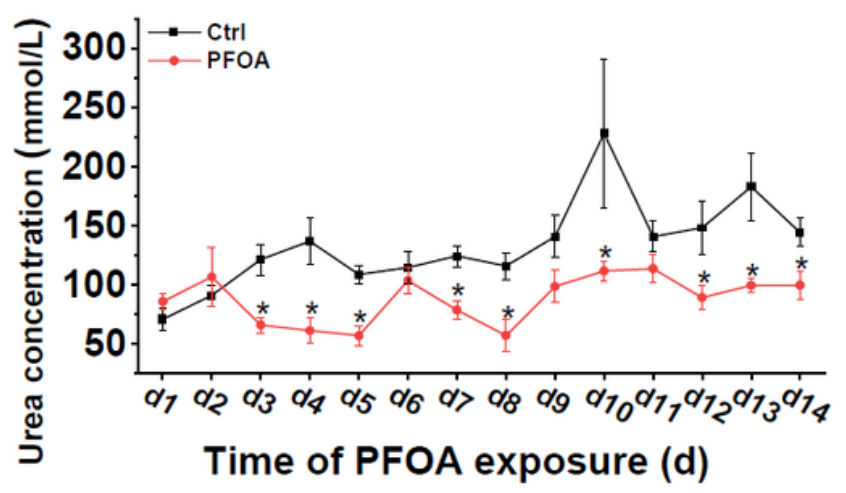

\section{Figure 2}

PFOA exposure can affect the urea metabolism. A. PFOA exposure does not change daily food intake in rats. B. Urea concentration in rats' urine decreased significantly after PFOA exposure. Mean $\pm S E M ; n=5$; ${ }^{\star} p<0.05 ;{ }^{* \star} p<0.01$ (control group vs. PFOA treated groups). 
A

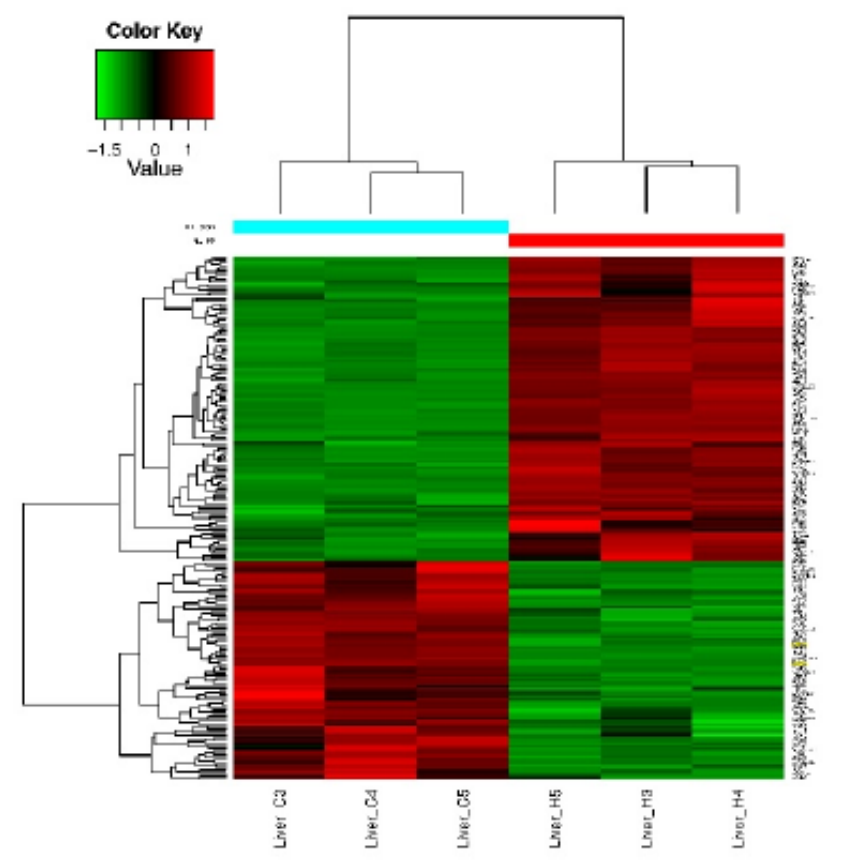

B

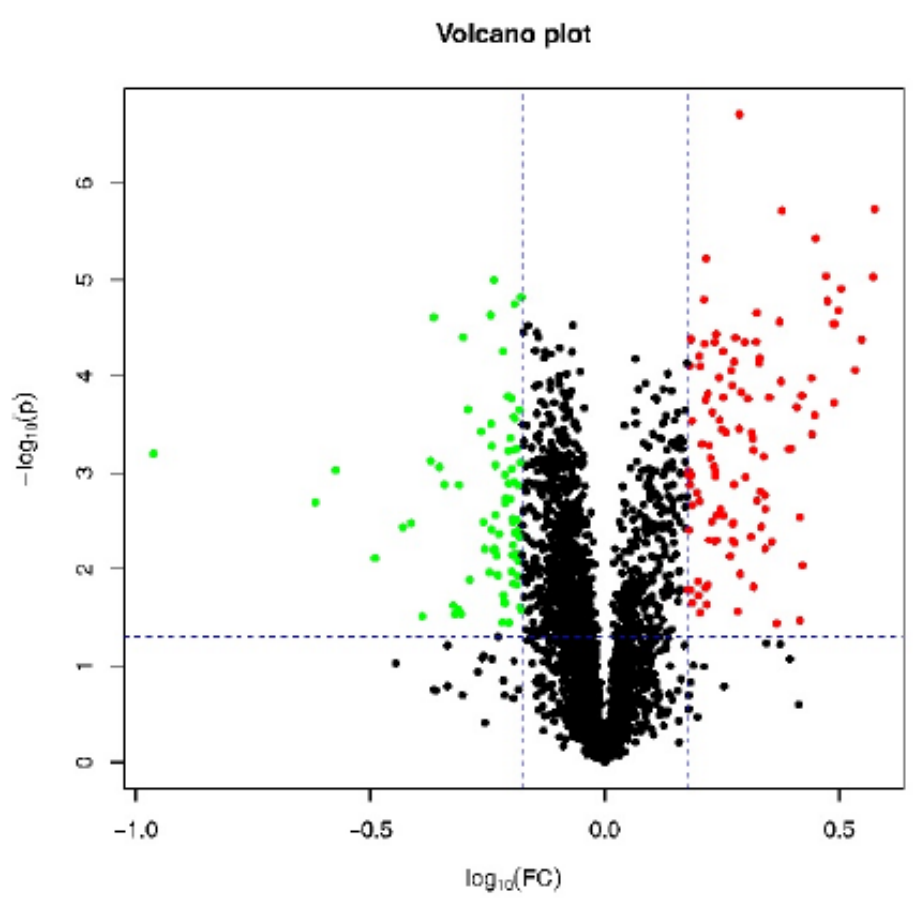

\section{upregulated downregulated}

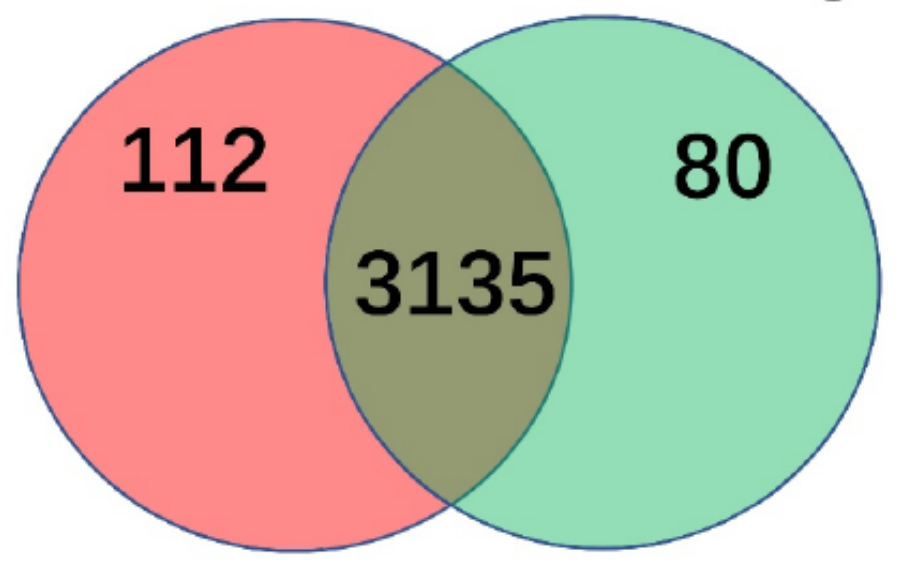

Figure 3

Proteomics analysis of rat liver tissues after PFOA exposure using isobaric tags for relative and absolute quantification (iTRAQ). A. Heatmap of identified proteins. Red colour refers to upregulated proteins, green colour refers to down regulated proteins. B. Volcano plot of identified proteins. C. Venn diagram shows the overlap of upregulated, downregulated and total identified proteins, of which, 112 proteins were significantly upregulated and 80 proteins were downregulated. 
A Function Classfication(GO) of upregulated proteins

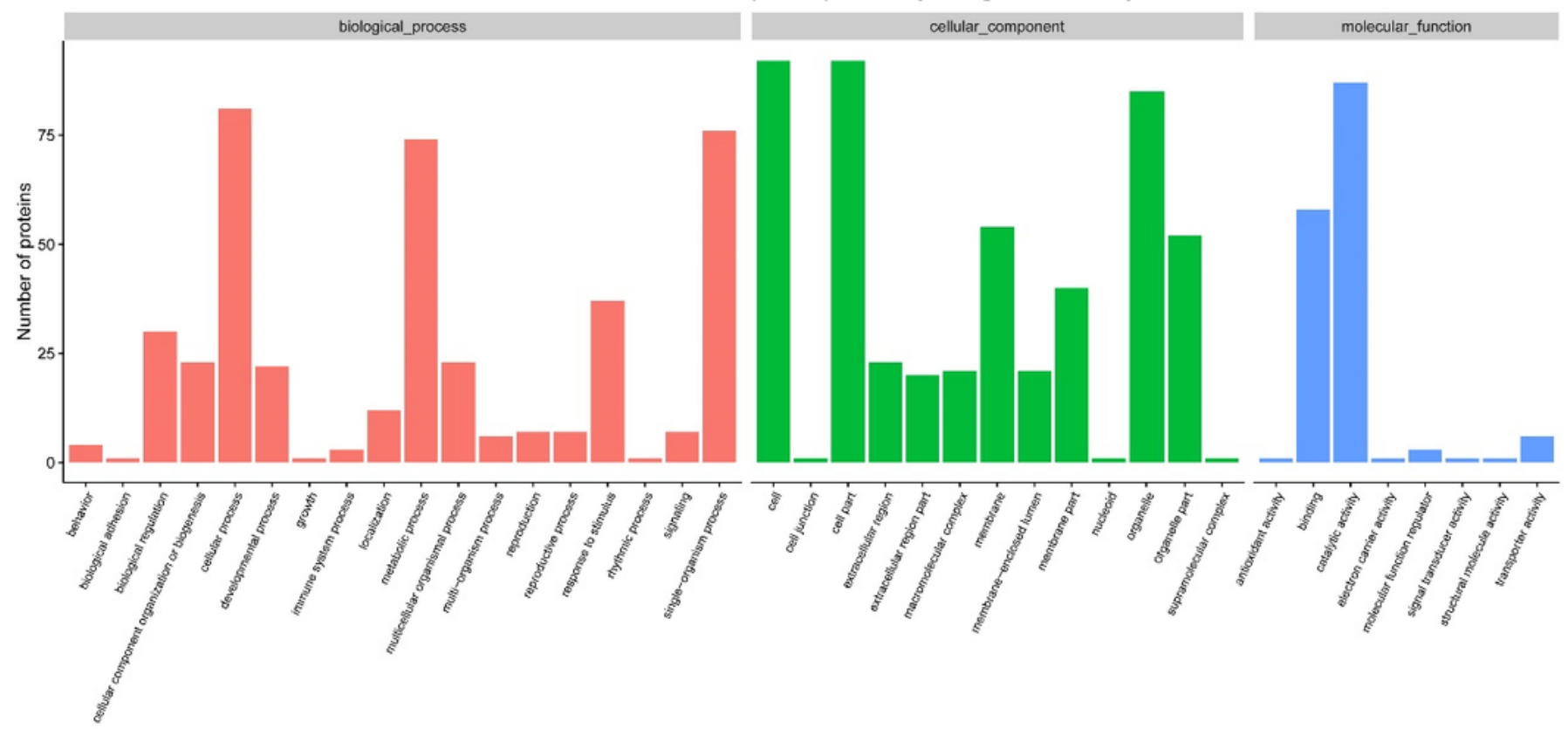

B

\section{Function Classfication(GO) of downregulated proteins}

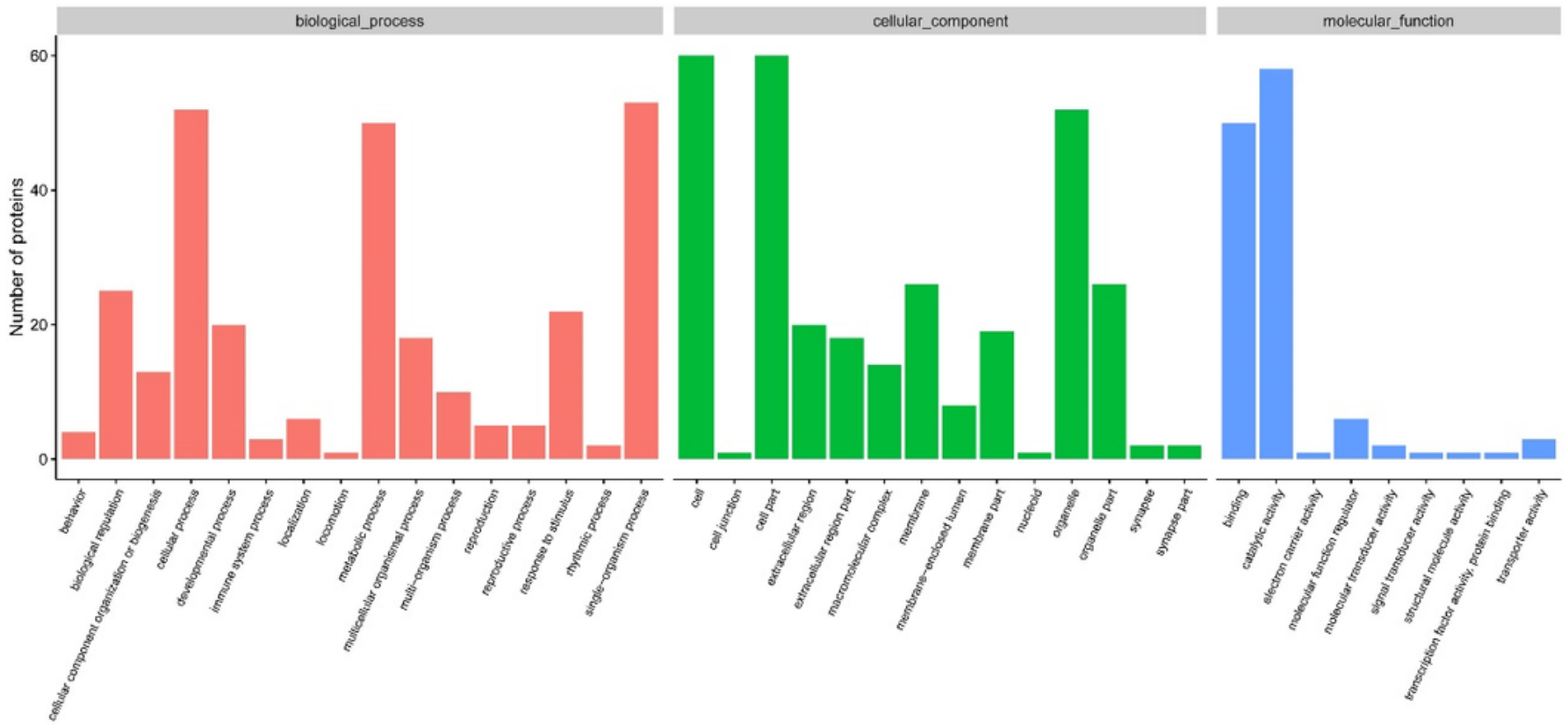

Figure 4

Gene Ontology (GO) analysis of different expressed proteins in rat liver tissues after PFOA exposure. A. Function classfication of upregulated proteins. B. Function classfication of downregulated proteins. 


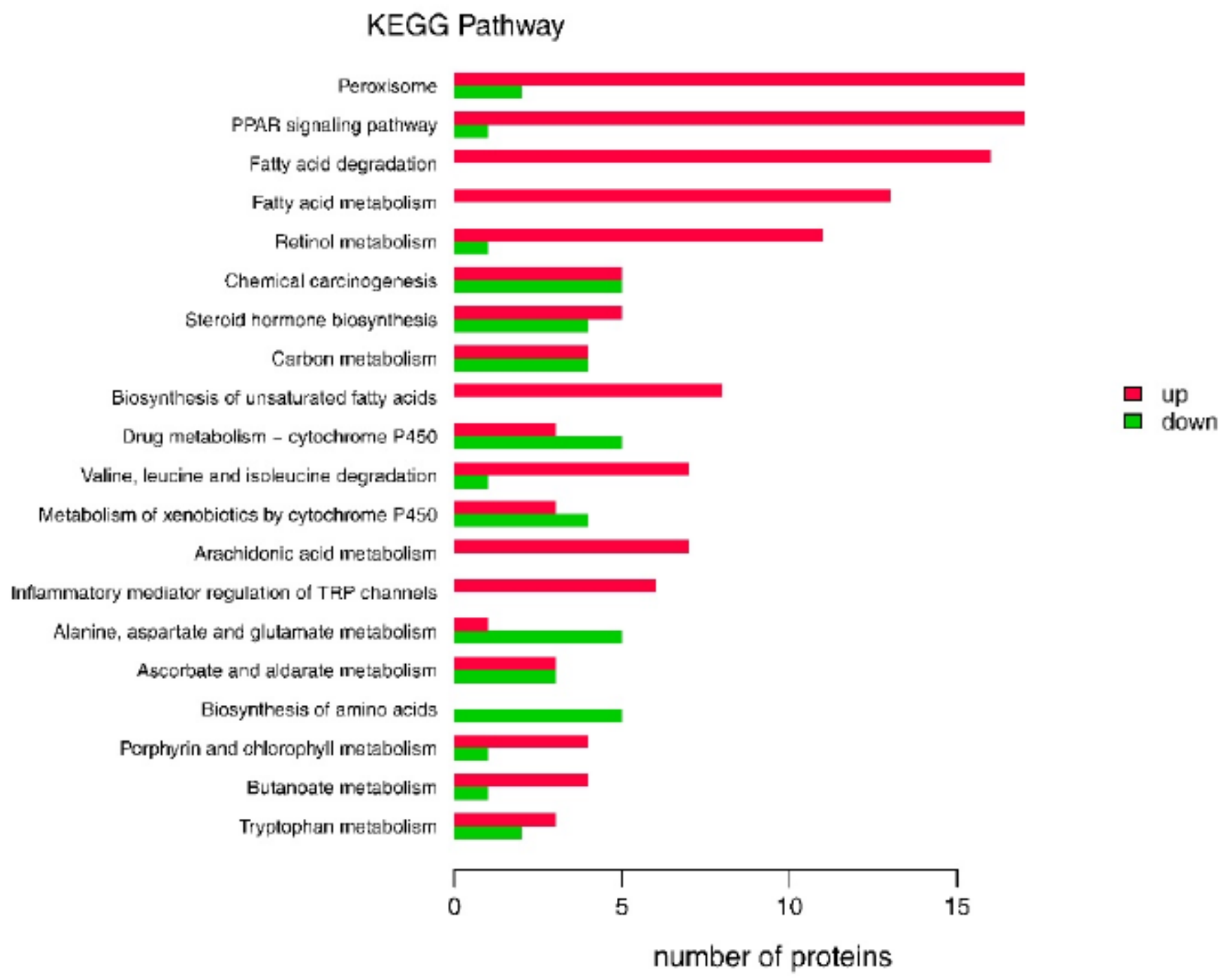

\section{Figure 5}

Kyoto Encyclopedia of Genes and Genomes (KEGG) analysis of different expressed proteins in rat liver tissues after PFOA exposure. 
A

Oxidation of fatty acid

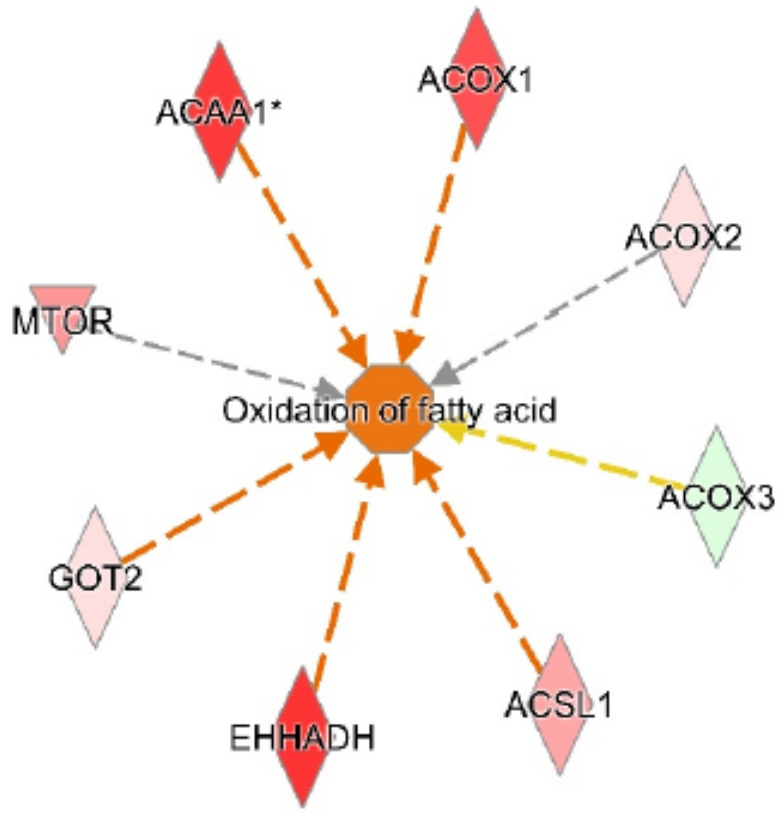

Urea cycle disorder

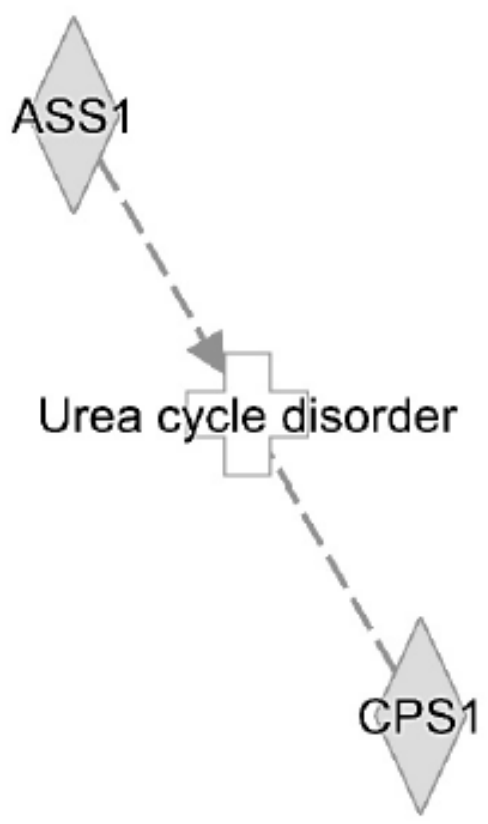

Figure 6

Ingenuity Pathway Analysis (IPA) of some interesting DEPs (different expressed proteins). A. Network of different expressed proteins related to oxidation of fatty acid. B. Network of different expressed proteins related to urea cycle disorder.

A

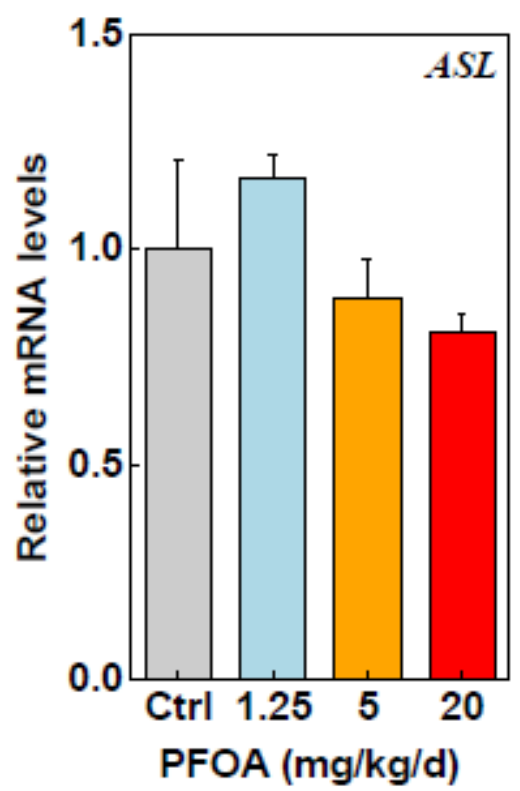

B

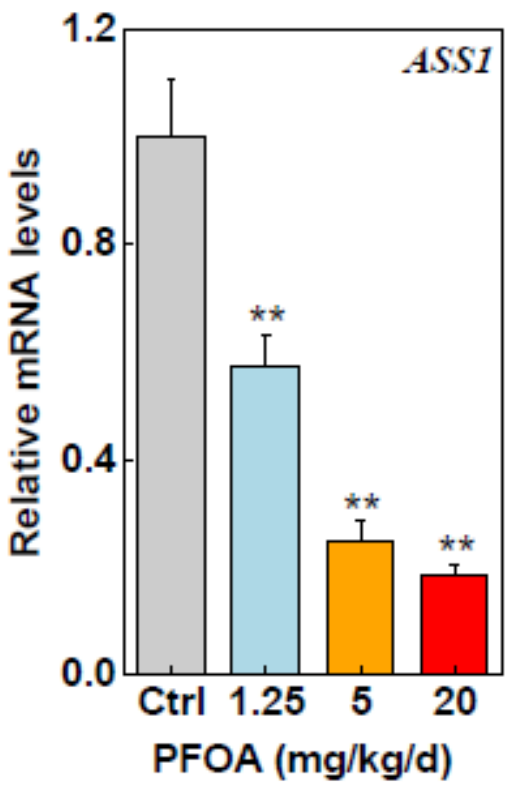

C

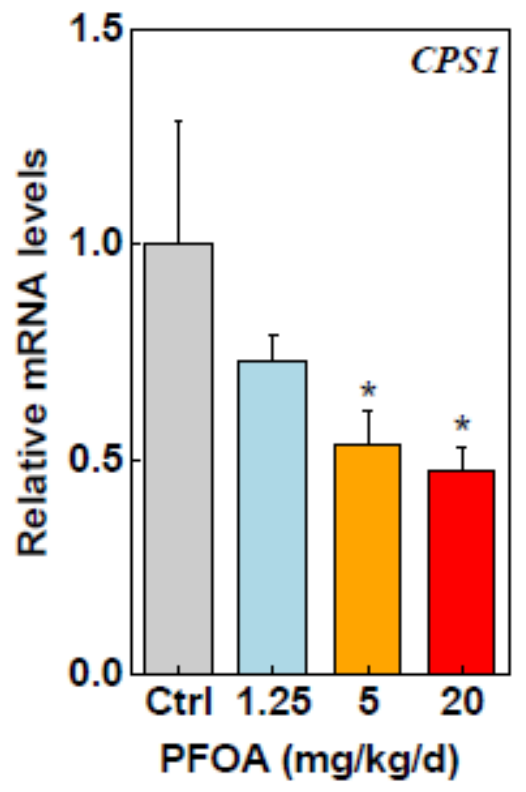


Figure 7

Quantitative RT-PCR analysis of rat liver mRNA transcription levels of control and PFOA treated groups at various concentrations. Mean $\pm \mathrm{SEM} ; \mathrm{n}=6{ }^{*} \mathrm{p}<0.05 ;{ }^{* \star} \mathrm{p}<0.01$ (control group vs. PFOA treated groups). Asl: Argininosuccinate Lyase; Ass1: Argininosuccinate Synthase 1; Cps1: Carbamoyl-Phosphate Synthase 1.

A

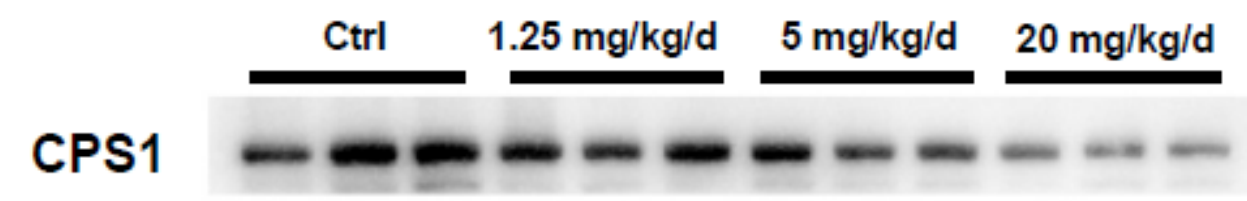

ASS1

GAPDH

B
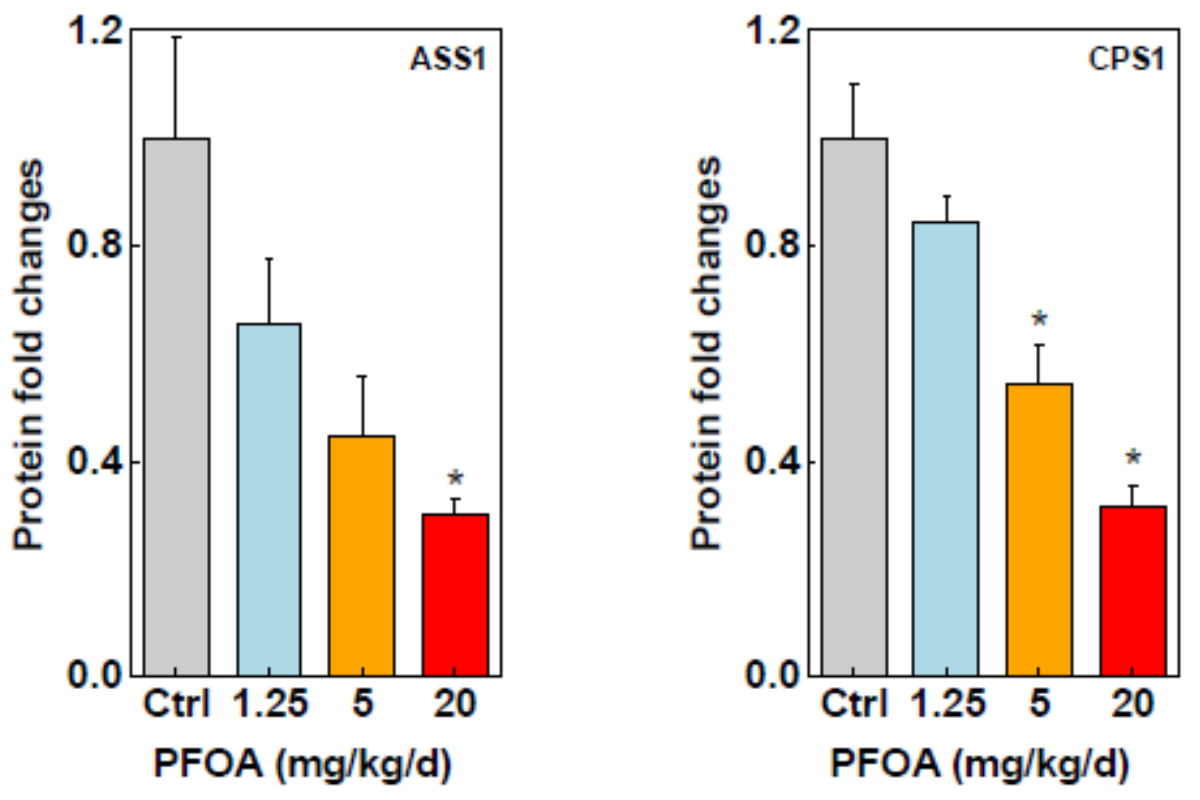

Figure 8

Western blot analysis of rat liver protein expression levels of control and PFOA treated groups at various concentrations. A. Protein levels of CPS1 and ASS1 in rat livers after PFOA treatment. Protein intensities were normalized to the corresponding internal reference protein GAPDH level. B. Results from densitometry analysis of the western blots in A. Mean \pm SEM; $n=6{ }^{*} p<0.05 ;{ }^{*} p<0.01$ (control group vs. PFOA treated groups). 


\section{Supplementary Files}

This is a list of supplementary files associated with this preprint. Click to download.

- Tables1.pdf

- Tables2.pdf

- TableS3.pdf

- Tables4.pdf 